\title{
Kajian dan penulisan kearifan budaya Melayu Jambi dengan pendekatan jurnalisme sastra, berbasis penelitian budaya lokal
}

\author{
Eddy Pahar Harahap ${ }^{1}$, Kamarudin² \\ Universitas Jambi \\ Correspondence : eddypahar44@gmail.com
}

\begin{abstract}
In the context of cultural wisdom, it is no longer seen as hereditary heritage but cultural wisdom is the strength of the creative industry based on cultural wisdom. Students of the language and literature study program who have writing and literary skills are able to study and write cultural wisdom. With the ability to study and write local wisdom allows students as; entrepreneurship, creator, humanist, writer based on the strategy of cultural wisdom values. The research focus is the study and writing of Jambi Malay cultural wisdom with a literary journalism approach. Literary journalism is a feature-oriented creative writing skill based on facts in the field. To achieve this, the study and discussion refers to the practice of improving learning; Research and development; Classroom Action Research, and Project-Based Learning. The results of research on student abilities; write the title of 'good' level, write the intro at 'good' level, the type of intro written; storytelling, descriptive, and questions, writing the atmosphere of the story as a result of observation at the 'medium' level, writing the dialogue of the results of the investigation and reporting at the 'medium' level, (5) closing the story containing the message at the 'good' level, the type of message written; view of life, sincerity, and a call to action. Overall the ability to write knowledge of Malay culture is based on the 'good' range. Based on this the suggestions put forward; feature as a creative essay, very easy to develop by students as novice writers, so that they are interested in composing the potentials of local wisdom; data features on the basis of the results of field research through the process of observation, interviews, investigations and reporting. Based on the suggestions put forward, the literary journalism approach can be developed well in learning creative writing.
\end{abstract}

Keyword: cultural wisdom, literary journalism 


\section{Pendahuluan}

Indonesia merupakan negara multikultural yang memiliki keragaman budaya yang melahirkan berbagai kearifan budaya lokal. Sejalan dengan perkembanganya, pada konteks kekinian kearifan budaya lokal tidak lagi dipandang sebatas pengetahuan atau kebiasaan yang diwariskan secara turun temurun tetapi kearifan budaya merupakan kekuatan industri kreatif yang berbasis pada kearifan budaya lokal.

Sebagai kekuatan industri kreatif berarti bangsa Indonesia sudah pada fase keempat. Dalam fase keempat ini peradaban ditandai dengan ekonomi kreatif berbasis budaya, seperti perpekstif Toffler dalam bukunya, 'The Third Wave' (dalam, Anoegrajekti, 2013). Toffler yang menggunakan istilah 'gelombang' (wave); gelombang era pertanian adalah muscle (otot), gelombang era industri machine (mesin), dan gelombang era informasi yang menonjol adalah mind (pikiran, pengetahuan) dan saat ini memasuki fase keempat yakni gelombang budaya menjadi komoditas utamanya. Taum (2013) bahwa pada saat ini terjadi perubahan paradigma pembangunan ekonomi berbasis pertanian, industri, dan teknologi ke kreativitas berbasis budaya.

Kreativitas berbasis budaya inilah telah mengemuka berbagai pemikiran bahwa peradaban bangsa Indonesia ke depan sangat diperkuat oleh nilai-nilai strategis kearifan budaya di masyarakat. Pemikiran-pemikiran yang berhubungan nilai stategis kearifan budaya sebagai kekuatan peradaban bangsa Indonesia, di antaranya yang dapat dikemukakan dalam tulisan ini; Amirin (2011) Pendidikan Multikultural Kontekstual Berbasis Kearifan Lokal; Ningsi (2013) dan Suyitno (2012) Pendidikkan Karakter Berwawasan Kearifan Lokal Dalam Melestarikan Lingkungan Hidup; Sukamto (2013) Keanekaragaman Bahasa Dan Industri Kreatif; Anoegrajekti (2013) Industri Kreatif Berbasis Lokalitas, Dialektika Sastra; (Taum, 2013) Sastra Lisan Dan Ekonomi Kreatif; dan Permatasri (2013) Pembelajaran Bahasa Yang Menarik Dan Aplikatif Salah Satu Implementasi Industri Kreatif di Indonesia. Dengan pemikiran-pemikiran yang dikemukakan sudah dipastikan bahwa pengkajian dan penulisan nilai-nilai strategis kearfan di Perguruan Tinggi harapannya sebagai muatan pembelajaran di berbagaibidang ilmu.

Kekuatan kearifan budaya sebagai potensi industri kreatif menerbitkan Instruksi Presiden no.6/2009 (Pangestu, 2008) yang berisikan 14 cakupan ekonomi kreatif berbasis budaya, antara lain; 1) jasa periklanan, 2) arsitektur, 3) seni rupa, 4) kerajinan, 5) desain, 6) mode, 7) film, 8) musik, 9) seni pertunjukkan, 10) penerbitan, 11) riset dan pengembangan, 12) software, 13) TV dan Radio, dan 14 vidio game. Taum (2013) mengemukakan keempat belas ekonomi kreatif ini menjadi konsep ekonomi baru di Indonesia yang berorientasi pada kreativitas warisan budaya dan lingkungan. Konsep inilah menjadi cetak biru tercapainya visi dan misi industri kreatif di Indonesia sampai tahun 2030. Taum juga berpendapat Indonesia memang sangat kaya akan berbagai warisan 
budaya leluhur dari seluruh pelosok nusantara. Warisan budaya itu memiliki banyak nilai kreativitas yang melibatkan berbagai aspek seperti art, beauty, design, play, story, humor, syimphony, caring dan meaning.

Begitu juga dengan perkembangan teknologi informasi yang juga sangat memacuh dan memicuh daya kreativitas berbasis kearifan budaya lokal semakin berkembang. Harapannya dengan teknologi informasi adalah suatu peluang bagi kum milenial seperti mahasiswa untuk mengkaji,menulis serta mempublis hasilhasil kajian baik secara individu maupun komunitas. Tidaklah suatu per diperdebatkan bahwa daya kreasi akan mempengaruhi penjelmaan kearifan budaya sedikit konteporer, karena ada faktor rekayasa dan modivasi kearifan budaya lebih kekinian. Hal ini tidaklah masalah kearifan budaya lokal semakin dinamis walau tidak meninggalkan keasliannya sebagai ciptaan masa lalu. Dengan demkian dapat dikatakan sebagai ciptaan masa kearifan budaya lokal sebagai mekanisme sosio-kultural yang terdapat dalam tradisi masyarakat. Gidden (2001) dalam prosesnya kebanyakan apa yang dianggap tradisi di masa kini, telah melewati batas waktu dengan mengalami penyesuaian dengan perkembangan-perkembangan baru. Beberapa pendapat yang dikemukakan, artinya bahwa budaya masa lalu dapat direvitalisasi untuk memperkuat identitas suatu kelompok sosial, sekalipun budaya itu tidak lagi asli sebagaimana budaya itu hidup dan dimaknai di masa lalu.

Mahasiswa Program Studi Bahasa dan Sastra sebagai sebagai pembelajaran di Perguruan Tinggi tentu sudah memiliki kemampuan menulis dan kemampuan bersastra. Dua kemampuan produktif ini tentunya sebagai dasar dalam mengkaji dan menulis kearifan budaya lokal. Ke depan dapat diyakini mahasiswa bahasa dan sastra yang memiliki kemampuan mengkaji dan menulis kearifan budaya lokal mereka dapat mengembangkan diri untuk berprofesi sebagai; entrepreneurship, kreator, budayawan, sastrawan yang berbasis pada pengembangan nilai-nilai strategis kearifan budaya lokal di daerahnya.

Keuntungan yang akan mereka peroleh dengan profesi tersebut; (1) mahasiswa bahasa dan sastra secara tidak langsung sudah melestarikan dan mengembangkan budaya leluhur secara kreatif, dan (2) perkembangan serba digital secara personal mahasiswa bahasa dan sastra berpeluang mempublikasi dari hasil kajian dan penulisan yang memungkinkan mereka akan menjadi kreator dari beberapa cakupan ekonomi kreatif berdasarkan Instruksi Presiden no.6/2009 tersebut. Beberapa cakupan ekonomi kreatif berbasis budaya yang berhubungan dengan kemampuan menulis dan bersastra adalah mengkaji dan menulis serta mempublikasi secara feature seperti; seni pertunjukan, foklor di daerahnya, berbagai kerajinan tradisional, kuliner tradisonal, permainan rakyat, cerita rakyat, dan penerbitan.

Sampai saat ini, tampaknya belumlah banyak mahasiswa bahasa dan sastra memiliki motivasi mengkaji dan menulis kearifan budaya lokal. Hal ini 
mungkin disebabkan model pembelajaran menulis belum berfokus pada bahan pembelajaran mengkaji dan menulis kearifan budaya. Jika demikian permasalahan, maka diperlukan perubahan pembelajaran menulis dari learning style tetapi merupakan learning activities. Terciptanya learning activities dalam pembelajaran maka skanario pembelajaran yang diterapkan; (1) peran dosen lebih banyak menjadi pembimbing, (2) pembelajaran berdasarkan fakta atau penelitian. Kedua skanario ini sangat sesuai untuk meningkatkan motivasi dalam pembelajaran menulis kreatif, seperti menulis kearifan budaya lokal. Hal ini sejalan dengan pendapat Syafi'ie (1998) bahwa sumber pengumpulan bahan tulisan yang akurat adalah observasi, membaca, dan inferensi.

Seperti pemikiran yang diuraikan berarti diperlukan suatu model pembelajaran menulis khususnya pada kemampuan mengkaji dan menulis kearifan budaya secara learning activities yang sesuai dengan kemampuan mahasiswa sebagai penulis dan peneliti pemula. Strategi pencapaian learning activities kegiatan belajar tentu autentik melalui perencanaan (designing) dan investigasi (open-ended) dengan hasil yang prespektif (Djumingin,S, 2016) membangun pengetahuan dunia nyata dengan interaksi kognitif interpersonal yang kolaboratif serta membantu peserta didik/mahasiswa untuk meningkatkan belajar mandiri dan kompetensi keterampilan berpikir kritis (critical thinking sills) dan Case Based Learning (CBL) melatih peserta didik/mahasiswa untuk mengeksplorasi dan memecahkan masalah dari kasus nyata yang sajikan pendidik dosen. Apalagi saat ini dengan Kurikulum Kampus Merdeka, Merdeka Belajar di Perguruan Tinggi sangat diharapkan pengembangan keterampilan berpikir kritis (critical thinking sills); case based learning (cbl); case method; dan PjBL.

Barangkali tidaklah hal yang baru untuk mahasiswa bahasa dan sastra dalam melakukan pengkajian dengan metode observasi dan investigasi artinya bukanlah suatu hal yang sulit untuk dilakukan dilapangan, malah diasumsikan kegiatan observasi dan investigasi menyenangkan untuk mendapatkan data-data kebahasaan dan kesastraan. Data-data seputar bentuk dan sejarah serta nilainilai strategis yang terkandung kearifan budaya lokal tentu dilakukan dengan observasi dan investigasi.

Yang menjadi permasalahan selama ini, hasil kajian tersebut dituntut dengan prosedur penulisan karya ilmiah. Di sinilah terkadang sulitnya mahasiswa mengembangkan gagasan di setiap paragraf. Mahasiswa agak terbelengu dengan laras bahasa baik dan benar sehingga tidak ada percepatan untuk membangun motivasi dan kemauan menulis kreatif dan mandiri. Sebagai penulis pemula ada baiknya penelitian yang dilakukan Dewi (dalam Siswanto, 2014) kepada mahasiswa semester II (dua) mata kuliah Writing 1 (satu) Bahasa dan Seni, Universitas Pendidikan Ganesha, menyimpulkan bahwa kemampuan mahasiswa untuk mengembangkan paragraf naratif lebih bagus dari pada paragraf deskriptif. Penelitian Dewi ini laporan bersifat naratif bisa menjadi 
jalan keluar agar mahasiswa mau menulis kreatif di dalam tugas-tugas kuliah. Mungkin ada beberapa keraguan, apakah tidak berpengaruh dengan tugas akhir yang mengharus mahasiswa menggunakan prosedur tulisan ilmiah. Dalam pembelajaran menulis, mahasiswa sudah dipastikan memahami mana tulisan ilmiah dan tulisan semi populer. Dimasa mendatang tulisan semi popular dan sedikit bersastra adalah jenis tulisan yang dibaca oleh para kaum milenial; seperti feature, cerpen dan novel. Jenis-jenis tulisan ini diasumsikan sangat efektif untuk meningkatkan kemampuan dan kemauan mahasiswa menulis nilainilai kearifan budaya lokal.

Dalam hal ini, penulis telah mengembangkan pendekatan yang mengkolaborasi kemampuan dan kemauan mahasiswa mengkaji dan menulis secara kreatif dan mandiri dengan pendekatan jurnalisme sastra. Sebenarnya pendekatan ini sangat dekat dengan profesi wartawan maupun reporter. Harsono (2005) mengemukakan jurnalisme sastra memiliki proses peliputan data melalui strategi; observasi, investigasi dan reportase yang dilakukan secara mendalam, dan dalam penulisannya dilakukan secara sastrawi sehingga enak dibaca. Jurnalisme sastra menghasilkan karya tulis artikel naratif yang bernama feature.

Richard Winer (dalam, Sumadira, 2012), feature adalah artikel atau karangan yang lebih ringan, atau lebih umum, tentang daya pikat manusiawi atau gaya hidup daripada berita lempang yang ditulis dari peristiwa yang masih hangat. Dengan pendapat yang dikemukan, secara umum jurnalisme sastra dapat diartikan adalah kolaborasi proses jurnalistik dan proses penulisan bergaya sastra. Proses jurnalistiknya pada wilayah pengambilan data lapangan dengan metode observasi dan investigasi. Reportase atau laporannya mengikuti tulisan, tuturan gaya sastrawi, yakni adanya unsur instrinsik, seperti; ada tema, adegan, plot, dialog karakter, gaya, suasana, lokasi pesristiwa, dan sudut pandang orang ketiga.

Dengan pemikiran yang diuraikan, pendekatan jurnalisme sastra yang dikembangakan dalam bentuk penelitian. Penelitian tersebut bertajuk 'Kajian dan Penulisan Kearifan Budaya Melayu Jambi Dengan Pendekatan Jurnalisme Sastra, Berbasis Penelitian Budaya Lokal'. Ada pun singtag-sintag yang diterapkan dalam penelitian berbasis penelitian budaya Melayu Jambi dikemukakan sebagai berikut.

1. Kajian dilakukan melalui proses jurnalisme/jurnalistik meliputi sintag-sintag; pengambilan data ini dilakukan secara proses jurnalistik, yakni; observasi dan investigasi (wawancara) kepada nara sumber.

2. Hasil data lapangan ditulis direportase dengan artikel feature bergaya sastrawi memiliki unsur-unsur kelengkapan dalam tulisan, antara lain; judul, intro, adegan, plot, dialog karakter, gaya, suasana, lokasi peristiwa, dan sudut pandang orang ketiga, serta pesan moral sebagai penutup cerita.

Karya jurnalisme sastra adalah feature, dalam dunia jurnalistik feature adalah soft news (berita ringan). Daniel R. Williamson (dalam, Sumadiria 
(2005), feature adalah artikel yang kreatif, kadang-kadang subjektif yang dirancang terutama untuk menghibur dan memberitahu pembaca tentang peristiwa, situasi, atau aspek kehidupan. Harris, Julilan,The Complete Reporter (1985), Richard Weiner dalam Webster's New Word Dictionary of Media Cumunication (1990) dan Daniel R. Williamson - Feature Writing for Newspaper (1975) feature sebagai tulisan kreatif yang terutama dirancang guna memberi informasi sambil menghibur tentang suatu peristiwa, situasi, atau aspek kehidupan seseorang. Richard Winer (dalam, Sumadira, 2005), feature adalah suatu artikel atau karangan yang lebih ringan, atau lebih umum, tentang daya pikat manusiawi atau gaya hidup daripada berita lempang yang ditulis dari peristiwa yang merupakan cerita atau karangan khas yang berpijak pada fakta dan data yang diperoleh melalui proses jurnalistik. Ringkasnya, feature adalah karangan yang melukiskan suatu pernyataan dengan lebih rinci sehingga apa yang dilaporkan hidup dan tergambar dalam imajinasi.

Setiap surat kabar yang dikelola secara profesional dan memiliki kredibilitas serta reputasi baik pasti memberi tempat terhadap feature. Walaupun, feature sebagai pelengkap informasi tetapi feature pemberi informasi menarik tentang keadaan dan peristiwa yang terjadi, feature juga sebagai penghibur sarana rekreasi dan pengembangan imajinasi yang menyenangkan, serta memberi nilai dan makna terhadap peristiwa tersebut. Fungsi-fungsi ini pada dasarnya mudah dipahami, dikaji dan ditulis mahasiswa.

Feature adalah cerita pendek yang diangkat dari realitas objektif. Realitas objektif, sesuatu yang faktual, benar, nyata adalah rangkaian informasi yang dibangun dari hasil visitasi konfirmasi, dan adakalanya investigasi. Sedangkan realitas fiktif, kalaupun asalnya diambil dari dunia nyata, ia dibangun berdasarkan kreativitas dan imajinasi sang pengarang. Karena bersifat cerita pendek, maka dalam pengembanganya menulis feature agak dijauhkan dengan kaidah-kaidah kebahasan yang terkadang menjadi momok bagi penulis pemula.

Dalam hal penulisan feature bersifat artikel naratif sastra, yaitu memiliki unsur-unsur; tema, intro, adegan, plot, dialog karakter, gaya, suasana, lokasi peristiwa, dan sudut pandang orang ketiga, serta pesan moral yang disampakan. Oleh karena itu feature dikatakan sebagai jenis menulis kreatif memang sangat sesuai untuk membangun minat menulis kreatif mahasiswa sebagai penulis pemula. Sangat sesuai yang dimaksud karena menulis feature mengandung juga unsur-unsur penelitian lapangan, yakni ada tahapan observasi, wawancara, dan pelaporan mengikuti gaya sastrawi.

Provinsi Jambi pada umumnya Suku Melayu Jambi, yang terdiri dari Melayu Batin, Kerinci, Penghulu, Pindah, dan Anak Dalam (Kubu) dan Bajau. Suku Melayu Jambi ini memiliki nilai-nilai budaya lokal, seperti pakaian, kesenian, senjata, arsitektur, upacara (Profil Provinsi Jambi, 1992). Namun, dalam penelitian yang telah dilakukan tidaklah berfokus kepada nilai-nilai 
budaya itu.Penelitian lebih difokuskan kepada kemampuan mahasiswa mengkaji dan menulis kearifan budaya Melayu Jambi.

\section{Metode}

Fokus penelitian ini adalah kajian dan penulisan kearifan budaya Melayu Jambi dengan jurnalisme sastra. Karya jurnalisme sastra adalah feature yang berorientasi pada keterampilan menulis kreatif berdasarkan fakta di lapangan. Untuk mencapai hal tersebut maka penelitian kajian dan penulisan merujuk ke beberapa praktik perbaikan pembelajaran yang dapat dipertangungjawabkan. Dengan demikian, ada beberapa acuan yang menjadi pegangan dalam penelitian; Research and Develoment; Classroom Action Research, dan Project Based Learning. Sukmadinata (2009:164) tujuannya Research and Develoment untuk memperbaiki praktik pembelajaran. Sutiah (2008, dalam Sukmadinata, 2009: 170) pengembangan Research and Develoment dapat menghasilkan produk penelitian terapan yang dapat dipertanggungjawabkan.

Untuk membangun aspek kognitif, afektif dan psikomotoriknya mahasiswa dalam menggali/mengkaji masalah, menemukan masalah, dan memecahkan masalah (Dewi, Citra dan Abdul (2015, dalam Ainin Nurul, 2019) kearifan budaya lokal Melayu Jambi dilakukan dengan diskusi kelompok dalam naungan kendali pendidik/dosen sehingga mahasiswa dapat secara leluasa membangun kompetensi dalam dirinya, baik di dalam kelas maupun di lapangan

Subjek penelitian adalah 40 orang mahasiswa semester VI. Setiap mahasiswa diwajibkan mengkaji dan menulis satu kearifan budaya di kabupaten masing-masing. Topik yang dikaji dan ditulis mahasiswa berupa; tradisi, adatistiadat, makanan tradisional, rumah sejarah, kerajinan dan permainan rakyat yang berpotensi dikembangkan menjadi industri kreatif berbasis lokal. Oleh karena itu, dalam penelitian ini mahasiswa dikatakan sebagai 'human instrumen' yang telah dibekali pengetahuan teknik observasi, investigasi dan teknik reportase feature.

Jenis data dalam penelitian ini bersifat kualitatif dan kuantitatif. Data kualitatif yang berupa berupa kata, frase, dan kalimat dalam menulis; judul, adegan, plot, dialog, suasana, lokasi, sudut pandang orang ketiga dan pesan moral sebagai penutup tulisan di dalam feature. Data kuantitatif adalah rata-rata kemampuan yang dikonversi menjadi data kualitatif pada jenjang 'sangat baik, baik dan kurang baik'.

Rubrik menjaring data kemampuan setiap mahasiswa menulis feature kearifan budaya Melayu Jambi merujuk pada pendapat Sumadiria ( 2014), yaitu teknik menulis feature, sebagai berikut.

1. Kemampuan menulis judul, dinilai berdasarkan unsur-unsur; fleksibel, menarik, ekspresif, dan cita rasa sastra. Bobot penilaian kemmapuan menulis judul ini maksimal berbobot dua puluh. 
2. Kemampuan menulis intro, dinilai berdasarkan unsur-unsur; ringkas dan jelas, komunikatif, serta memilih salah satu jenis intro yang telah disepakati dalam diskusi kelas. Bobot penilaian kemampuan menulis intro diberi bobot maksimal dua puluh.

3. Kemampuan mengembangkan ciri utama feature dalam tulisan kearifan budaya Melayu Jambi; yakni; adegan, dialog, sudut pandang orang ketiga. Bobot penilaian ciri utama ini berbobot maksimal dua puluh.

4. Kemampuan mengembangkan unsur pokok feature dalam tulisan, yakni ada; plot, karakter, dan lokasi peristiwa. Bobot penilaian unsur pokok ini diberi bobot maksimal dua puluh.

5. Kemampuan menulis pesan moral sebagai penutup feature. Bobot penilaian menutup cerita dengan pesan moral berbobot maksimal dua puluh.

Data keefektifan hasil pembelajaran dengan pendekatan jurnalisme sastra dijaring melalui angket. Konten angket menanyakan dua hal; (1) apakah menulis feature bisa membangun menulis kreatif secara mandiri, (2) apakah anda memiliki keinginan untuk mengkaji dan menulis kearifan budaya, hasil kajian dan tulisan itu anda publikasi ke media online, IG, FB, koran cetak lokal. Teknik analisis data yang digunakan adalah analisis deskriptif dan analisis isi tulisan dari aspek kemampuan menulis semua unsur-unsur feature kearifan budaya Melayu Jambi.

\section{Hasil dan pembahasan}

\section{Hasil penelitian}

Fokus penelitian ini adalah kemampuan mahasiswa Pendidikan Bahasa dan Sastra Indonesia FKIP Universitas Jambi melakukan kajian dan penulisan kearifan budaya Melayu Jambi dengan pendekatan jurnalisme sastra. Dengan pendekatan jurnalisme sastra maka paparan data berupa narasi-narasi dan persentase kemampuan berupa angka yang dikonversi dengan pemaknaaan kualitatif sangat baik, baik dan cukup. Paparan data tersebut sebagai gambaran kemampuan menulis judul sampai kepada kemampuan menulis penutup cerita feature kearifan budaya Melayu Jambi.

\section{Kemampuan menulis judul feature kearifan budaya Melayu Jambi bersifat; fleksibel, menarik, ekspresif, dan kepekaan cita rasa sastra.} Redaksi judul feature sangat berbeda dengan redaksi judul karya tulis; esay, ilmiah dan laporan. Redaksi judul feature secara lengkap bisa dikataan bersifat fleksibel, menarik, ekspresif dan, kepekaan cita rasa sastra. Sementara juga feature adalah cerita khas yang berpijak pada fakta yang dan berita berita ringan (soft news) yang direncanakan sekaligus menghibur pembaca, pendengar dan pemirsa. Berarti mahasiswa sebagai penulis pemula harus benar-benar memahami sifat-sifat kelenturan bahwa feature adalah berita ringan yang direncanakan sekaligus untuk menghibur. 
Berdasarkan analisis data bahwa 9 (sembilan) sembilan mahasiswa (22 persen) menulis judul feature kearifan budaya MelayuJambi 'sangat yang bersifat; fleksibel, menarik, ekspresif, improvisasi dan, kepekaan cita rasa sastra. Berikut ini dikemukakan judul-judul tersebut; Rumah Panggung Tua Peninggalan Arab Melayu, Kota Santri Bernuansa Melayu, Rumah Batu Desa Olak Kemang, Kemanakah Kau kompangan?, Tradisi Mantai Menjelang Bulan Ramadan, Kelik Elang, Kesenian Lokal Bersejarah, Tarian Topeng dari Muaro Jambi, Kisah di Balik Tugu Letnan Muda Sarniem Pahlawan Bajubang, dan Hok Thong Sebagai Saksi Perjuangan Rakyat Jambi

Berikutnya mahasiswa yang memiliki kemampuan ‘baik' sebanyak 20 (dua puluh) mahasiswa (50\%). Penilaian kategori baik ini karena ada ada satu sifat judul feature yang kurang jelas dari sifat; fleksibel, menarik, ekspresif, improvisasi, dan kepekaan cita rasa sastra. Satu sifat judul yaitu pada umunya sifat cita rasa sastra. Berikut ini dikemukakan beberapa judul yang mewakili setiap jenis kearifan budaya Melayu yang bersifat; fleksibel, menarik, ekspresif tersebut; Kue Tradisi Pernikahan Adat Melayu, Benteng Belanda Muara Tembesi, Kenduri Sko Adat Kerinci, Adat Perkawinan Pelawan, Dadung Kesenian Khas Batanghari, Tari Nek Pung, Tari Selampit 8, Tari Lukah Gilo, Tradisi Menyumbun Dari Kampung Laut, Ambung Saman Kerajinan Ladang Panjang, Gulai Talang Kuliner Warisan Leluhur Kecamatan Mersam, Tradisi Lisan Tauh dan Krinok, Selanjutnya adalah kemampuan mahasiswa menulis judul yang mendapat nilai 'cukup' sebanyak 11 (sebelas) mahasiswa (26\%). Kemampuan cukup ini berdasarkan penilaian bahwa judul yang ditulis lebih ke arah judul essay, walau masih tampak sifat fleksibel, menarik, ekspresif. Berikut ini dikemukakan judul-judul kategori cukup tersebut; Lubuk Larangan, Upaya Masyarakat Menjaga Ekosistem Sungai, Panen Ikan Lewat Tradisi Nubo, Trasdisi Naik Gerudo Dalam Adat Pernikahan Desa Mersam, Batik Khas Kuala Tungkal, Seloko Adat Jambi, Tarian Kelik Elang, Kelezatan Kue Padamaran Khas Jambi

\section{Kemampuan Menulis Intro Feature Kearifan Budaya Melayu Jambi.}

Kemampuan kedua adalah menulis intro. Dalam menulis feature sering terjadi materi bagus tetapi intro jelek hasilnya akan jelek, materi jelek intro bagus hasilnya bisa bagus. Berdasarkan analisis data, berikut ini dikemukakan jenisjenis intro yang dikembangkan mahasiswa sebagai pembuka tulisan feature kearifan budaya Melayu Jambi.

(a) Kemampuan mahasiswa menulis 'intro bercerita'. Intro ini mengajak pembaca ke realitas kisah cerita. Berdasarkan data penelitian 15 (lima belas) mahasiswa (25\%) menulis intro bercerita sebagai pembuka tulisan mereka. Berikut ini dikemukakan beberapa penulisan intro bercerita. 
Kota Santri Bernuansa Melayu Jambi

Dahulu Seberang Kota Jambi dikenal juga sebagai kota Serambi Mekah. Sekarang dikenal dengan kota santri, dikatakan kota santri karena disetiap kelurahan memiliki Pesantren. Pesantren tua yang bertahan sampai hari ini ada empat yakni Nurul Islam, Sa'adatud Darein, Al-Jauharein dan Nurul Iman. Nurul Iman adalah pesantren yang tertua, yang juga menjadi induk dari ketiga pesantren lainnya.

Rumah Batu Olak Kemang

Bila suatu ketika Anda berkunjung ke Desa Olak Kemang, Kecamatan Danau Teluk, Seberang Kota Jambi, Anda akan melihat rumah batu. Di Desa Olak Kemang, rumah batu ini merupakan bangunan yang cukup mencolok di tengah pemukiman Desa Olak Kemang. Menurut cerita Syarifah Aulia, seorang penjaga rumah batu tersebut, disebut rumah batu, karena rumah pertama yang dibangun di desa ini!.

(b) Kemampuan mahasiswa menulis 'intro deskriptif', intro hanya menggambarkan kisah peristiwa, tidak mengajak pembaca untuk masuk ke dalam cerita. Berdasarkan data penelitian, 10 (sepuluh) mahasiswa (20\%) menulis intro deskriptif. Berikut ini dikemukakan satu penulisan intro deskriptif dengan nilai 'baik'

Tradisi Lisan Tauh dan Krinok

Terdapat tradisi lisan yang menyatu di Bumi Langkah Serentak Limbai Seayun, tradisi ini yang sangat menarik untuk dilihat mata dan didengar telinga. Tradisi dan tarian ini berada di Dusun Koto Jayo Rantau Pandan kabupaten Bungo, Jambi. Sebagai daerah dengan masyarakat Melayu tentunya tarian menjadi hal yang sangat umum bahkan wajib ada dalam setiap acara-acara penting.

\section{Tari Selampit 8}

Tepat pukul o9.oo pagi kami mengunjungi salah satu rumah masyarakat di desa Jambi seberang kota. Nama yang empunya rumah adalah Pak Dani, beliau sedang mengadakan pesta adat. Ketika kami sampai telah terdengar alunan musik berdendang mengiringi empat pasang muda mudi menari dengan penuh ceria. Mereka menari Selampit 8, tarian tradisional masyarakat Jambi Seberang Kota.

(c) Kemampuan mahasiswa 'intro pertanyaan', intro yang bertujuan memancing menggelitik pembaca. Berdasarkan data penelitian, lima belas mahasiswa (25\%) menulis intro pertayaan Berikut ini dikemukakan satu penulisan intro pertanyyaan.

Tarian Topeng dari Muaro Jambi

Pernahkan anda mendengar tarian topeng?, tarian ini desa Muaro Jambi. Khas tarian topeng ini dilihat dalam kelucuan gerak dan kostum. Konon kabarnya, tarian topeng ini mempunyai sejarah sendiri kenapa kostum yang dipakai tidak menggunakan pakaian yang mewah dan mahal, tetapi hanya menggunakan pakaian bekas yang sudah lusuh dan compang-camping, ternyata itu berawal dari seseorang yang diasingkan karena mempunyai penyakit yang menular.

\section{Kemampuan Mengembangkan Ciri Utama Feature; Adegan, Dialog, Sudut Pandang Orang Ketiga.}

Kemampuan ketiga adalah kemampuan menerapkan ciri utama feature, yaitu adanya; adegan, dialog, sudut pandang orang ketiga. Kemampuan mahasiswa menerapkan ciri utama ini bisa juga dipakai untuk menilai kualitas sejauh mana 
mahasiswa benar-benar melakukan observasi dan investigasi di tempat objek kearifan budaya Melayu Jambi. Hasil koreksi hanya 10 (sepuluh) mahasiswa yang mengembangkan pandangan orang ketiga dalam menulis feature kearifan Budaya Melayu Jambi.

a. Kemampuan menulis adegan, kemampuan ini dipakai untuk menilai secara fokus suasana demi suasana, gaya cerita, seakan pembaca berada di lokasi tersebut. Adegan ini bisa dikatakan adalah kemampuan mahasiswa mengobservasi dan investigasi di lapangan. Sebagian besar mahasiswa atau 30 (tiga puluh) orang (75\%) sudah memiliki kemampuan 'baik' dalam menulis adegan sebagai gambaran kemampuan hasil observasi lapangan. Berikut ini dikemukakan penulisan adegan tersebut.

b.Kemampuan menulis dialog, kemampuan ini menggambarkan wawancara atau investigasi kepada nara sumber. Secara kuantitas kemampuan menulis 20 (dua puluh) mahasiswa (50\%). Berikut ini dikemukakan kemampuan mahasiswa menulis dialog hasil investigasi dengan nara sumber di lokasi kearifan budaya Melayu Jambi.

Kisah di Balik Tugu Letnan Muda Sarniem, Pahlawan Bajubang

"Assalamu'alaikum pakde, kedatangan kami kesini mau nanyo informasi tentang tugu pahlawan yang ado di deket SMA", kata Hibah "Wa'alaikumussalam, ayok masuk nak, duduk dulu yo kagek pakde ceritoin sejarah kenapo tugu tu”, Jawab Pak Mi'at. "Jadi kek gini nah ceritonyo nak", sambungnya...

Kelik Elang, Kesenian Lokal Bersejarah

"Hallo yuk Resti, lagi istirahat yo?"mau nanyo ni yuk, apo yo filosofi tari kelik elang ni yuk?" tanyaku. "Iyo dek lagi istirahat, nah kalu adek nak tau filosofinyo gini ceritonyo'.

c. Kemampuan Menulis Sudut Pandang Orang Ketiga. Kemampuan ini berisikan pandangan masyarakat tentang kearian budaya yang ditulis. Berikut ini satu data tentang sudut pandang orang ketiga.

Betangas Jelang Pernikahan

Nur Laila selaku salah satu masyarakat Sarolangun yang melakukan tradisi ini pada pernikahannya mengatakan bahwa manfaat betangas ini ialah untuk menghilangkan bau badan sang calon pengantin, karena calon pengantin tidak mandi selama hari pernikahannya. manfaat lain ialah dengan bermandi keringat ini akan memberikan sebuah ketenangan batin serta kesegaran bagi sang pengantin.

\section{Kemampuan Mahasiswa Menulis Unsur Pokok Dalam Feature; Plot, Karakter, Gaya, Lokasi Peristiwa.}

Kemampuan ini pada dasarnya mudah dilakukan mahasiswa mahasiswa bahasa dan sastra karena mereka memiliki kemampuan menulis cerita pendek hasil dari pembelajaran menulis sastra. Dari empat unsur pokok penulisan feature; plot, karakter, gaya, lokasi peristiwa.yang agak sulit dikembangan adalah karakter. Rata-rata kemampuan mahasiswa menulis unsur pokok ini pada umumya mahasiswa mendapat nilai 75-80, yakni kemampuan baik. 
Kemana Kau Kompangan?

'pak..pung..pung..pung...itulah suara musik tradisional kompangan'. Tidak banyak yang tau tentang tradisi ini, karena mulai banyaknya macam pergelaran seni yang lebih praktis dan gampang dimainkan. Kompangan adalah musik tradisional asli yang memadukan seni musik alat pukul rebana dengan tradisi Islam dan dipadukan dengan tarian khas budaya Melayu.

\section{Kemampuan Menulis Pesan Moral Sebagai Penutup Feature}

Yang terakhir adalah data kemampuan 'menulis pesan moral' di akhir feature. Dalam menulis feature kearifan budaya Melayu Jambi pesan moral yang diharapkan dikembangkan mahasiswa tentu berhubungan dengan pelestarian kearfan budaya tersebut. Kemampuan mahasiswa menulis pesan moral kearifan budaya Melayu Jambi dalam rentangan nilai 75-80 'baik'. Berikut ini ditampilkan beberapa penutup pesan moral yang ditulis mahasiswa dalammenulis feature kearifan budaya Melayu Jambi.

a. Menutup Cerita Dengan Pesan Moral Pandangan Hidup. Pesan moral ini berhubungan dengan nilai-nilai yang terkandung harus dilestarikan dalam kearifan budaya Melayu Jambi tersebut. Berikut ini dikemukakan pesan moral pandangan hidup dalam feature yang ditulis mahasiswa.

Tari Selampit

Dengan demikian, dalam Tari Selampit 8 terkandung pesan makna sebuah pergaulan yang baik dilandasi keimanan, saling menghargai, dan berperilaku bijaksana. Tentunya pandangan ini tidak terlepas dari falsafah hidup masyarakat Seberang Kota Jambi yang memegang teguh nilai-nilai keimanan sebagai landasan dalam setiap pergaulan.

b. Menutup Cerita Dengan Pesan Moral Keikhlasan. Pesan moral kehiklasan mengajak pembaca untuk menjaga kearifan budaya secara ikhlas. Berikut ini dikemukakan data pesan moral keikhlasan.

Pusako Bertuah

Setelah penelusuran kami di Seberang Kota Jambi, banyak sekali pengetahuan baru yang kami dapatkan dan membuat kami menyadari betapa kayanya Negeri Jambi ini akan sejarah dan budaya yang tetap lestari di tengah zaman yang kian modern. Semoga saja kelestariannya tetap terjaga hingga generasi mendatang dan tak habis tergerus zaman.

Adat Perkawinan Pelawan, Paliman menjadi Pengikatnya

Oleh karena itu sebagai generasi muda hendaklah paham adat paliman sebagai calon penerus bukan hanya karena keunikannya, namun juga karena memiliki nilai ataupun petuah yang dapat diambil hikmahnya dalam kehidupan berumah tangga.

c. Penutup ajakan bertindak, penutup ini mahasiswa menuliskan saran, imbauan, seruan dan ajakan kepada pembaca untuk melakukan suatu tindakan tertentu yang di anggap relevan dan sangat mendesak

\section{Dadung Kesenian Batang Hari}

Saat ini kesenian dadung sangat mengkhawatirkan hal ini dikarenakan kurangnya perhatian pemerintah setempat untuk melestarikannya. Banyak rebano siam rusak dan membutuhkan dana yang tidak sedikit untuk memperbaikinya. Datuk aziz mengatakan saat itu mereka latihan menggunakan rebana kompangan meskipun suara yang dihasilkan berbeda namun ini dilakukan agar kesenian ini tidak punah 


\section{Pembahasan}

Redaksi judul feature sangat berbeda dengan redaksi judul karya tulis; esay, ilmiah dan laporan. Redaksi judul feature secara lengakap bisa dikataan bersifat fleksibel, menarik, ekspresif, improvisasi dan, kepekaan cita rasa sastra. Bagi mahasiswa sebagai penulis pemula memerlukan beberapa kali untuk melakukan perbaikan redaksi. Dari hasil pengamatan yang menjadi perdebatan mahasiswa dikelas judul bernuansa kepekaan cita rasa sastra yang menjadi perbincangan, karena cita rasa kepekaaan sastra sulit diukur secara realis.

Sebagai penulis pemula menulis judul feature paling tidak bersifat menarik dan ekpresif bisa dikatakan suatu kemampuan awal menulis feature yang baik. Hal itu terlihat pada umumnya mereka kemampuan rara-rata pada kategori 'baik', sebanyak 20 mahasiswa. Sifat kepekaaan cita rasa sastra pada umumnya yang kurang tampak, hal ini disadari bahwa feature tidak begitu lazim dipelajari sebagai muatan pembelajaran menulis.

Berikutnya, dalam menulis feature sering terjadi; materi bagus tetapi intro jelek hasilnya akan jelek. Materi jelek, intro bagus hasilnya bisa bagus. Berikut ini dikemukakan jenis-jenis intro yang ditulis mahsiswa menulis feature kearifan budaya Melayu Jambi. Intro dalam feature dengan intro dalam karangan juga tidak sama. Intro dalam feature bersifat aktif, ringkas dan hidup. Namun hal ini, mahasiswa bahasa dan sastra tidak begitu mengalami kesulitan. Hal ini mereka telah terbantu dengan mata kuliah menulis cerita pendek. Jika pun ada kelemahan yakni pada sifat hidupnya; memulai dengan dialog, tanda tanya, klise, dan puisi.

Kemampuan menulis dialog dalam cerita pada dasarnya adalah kemampuan mahasiswa melakukan investigasi dan reportase di lapangan. Feature yang menarik adalah penulisan dialog akrab dan informal dengan gaya sederhana dan gaya lebih santai. Dialog akrab dan informal sudah baik tetapi masih di tengah cerita, mestinya bisa juga dilakukan pada intro cerita maupun penutup cerita (Semi, 1995)

Feature adalah karya jurnalistik bersifat kreatif. Sebagai karya kreatif maka dalam menutup feature peran mahasiswa sebagai penulis mesti dia berpikir sebagai jurnalis dan sebagai cerpenis. Pada bagian ini kemampuan mahasiswa secara kualitatif 'sedang', karena unsur cerpenis belum terlihat berdasarkan inspiratif. Dalam tulisan feature, biasanya pesan yang disampaikan seputar; perjuangan, kejujuran, keikhlasan, kesabaran, nilai-nilai peradaban. Oleh karena itu, feature sebagai karya jurnalistik sastra bukan cerita biasa, feature menceritakan peradaban. Kemampuan mahasiswa menulis pesan moral dalam feature pada umumnya 'baik'. 


\section{Kesimpulan}

Secara kualitatif kemampuan mahasiswa menulis judul feature kearifan budaya Melayu Jambi pada rata-rata kemampuan 'baik'. Secara kuantitatif delapan puluh persen mahasiswa sudah mampu menulis judul feature kearifan budaya Melayu Jambi berdasarkan sifat-sifat judul featuretersebut. Tidak mampunya mahasiswa meraih kemampuan 'sangat baik' dalam penulisan judul Kearifan Budaya Melayu Jambi, hal ini disadari mahasiswa sebagai penulis pemula belum terbiasa memajankan diksi-diksi ekspresif, improvisasi, dan khususnya kepekaan cita rasa sastra.

Kemampuan mahasiswa menulis intro feature kearifan budaya Melayu Jambi disimpulkan sudah 'baik' berdasarkan sifat aktif, ringkas dan hidup. Jenis intro yang dikembangkan; intro bercerita, intro deskriptif, dan intro pertanyaan. Kemampuan menulis suasana cerita adalah kemampuan mahasiswa menuliskan suasana secara detail dari hasil dari pengamatan atau observasi. Observasi ini adalah bagian penting kemampuan menulis feature. Hasil analisis data kemampuan mahasiswa menulis suasana cerita secara detail pada Kearifan Budaya Melayu Jambi pada tataran kemampuan 'sedang'.

Kemampuan menulis dialog dalam cerita pada dasarnya adalah kemampuan mahasiswa melakukan investigasi dan reportase di lapangan. Feature yang menarik adalah penulisan dialog akrab dan informal dengan gaya sederhana dan gaya lebih santai. Hasil analisis data, kemampuan mahasiswa menulis dialog pada Kearifan Budaya Melayu Jambi pada umumnya dalam tataran kemampuan 'baik'.

Feature adalah karya jurnalistik bersifat kreatif. Sebagai karya kreatif maka dalam menutup feature peran jurnalis berfungsi ganda; dia sebagai jurnalis dan dia sebagai cerpenis. Hasil penelitian, dikemukakan bahwa kemampuan mahasiswa menutup cerita feature Kearifan Budaya Melayu Jambi pada tataran kemampuan 'sedang'. Kemampuan mahasiswa menulis. Kemampuan mahasiswa menulis pesan moral dalam feature kearifan Budaya Melayu Jambi bermuatan pandangan hidup, keikhlasan, da ajakan bertindak pada umumnya 'baik'. Secara keseluruhan kemampuan mahasiswa menulis kearifan budaya Melayu berdasarkan disimpulkan pada pada rentang kemampuan 'baik'.

Berdasarkan simpulan hasil penelitian, saran yang dikemukakan dalam penelitian ini adalah; (1) feature sebagai jenis tulisan atau karangan kreatif, sangat mudah dikembangkan oleh mahasiswa sebagai penulis pemula, sehingga mereka termotivasi untuk mengarang potensi-potensi lokal, seperti; kearifan budaya lokal, industri kreatif, ekonomi kreatif, dan (2) data feature pada dasarnya hasil penelitian lapangan melalui proses onservasi, wawancara, investigasi maupun reportase, pengambilan data melalui hal-hal tersebut sangat menyenangkan dilakukan mahasiswa, sebagai peneliti muda. Berdasarkan dua butir saran yang dikemukakan, saran yang dikemukakan bahwa pembelajaran 
jurnalistik sastra sangatlah baik dikembangkan dalam pembelajaran menulis kreatif.

\section{Daftar pustaka}

Amirin, Tatang M. (2012). Implementasi Pendekatan Pendidikan Multikultural Kontekstual Berbasis Kearifan Lokal Di Indonesia. Jurnal Pembangunan Pendidikan. Volume I Nomor 1, Juni 2012. Fakultas Ilmu Pendidikan Unversitas Negeri Yogyakarta.

Ahmad Alim Wijaya, Syarifuddin, Aulia Novemy Dhita. (2021). Nilai-Nilai

Kearifan Lokal Rumah Adat Kajang Lako di Jambi. Jurnal Program

Studi Pendidikan Sejarah, Universitas Sriwijaya, Vol 10 (1) Februari 2021. Anoegrajekti, Novi. (2013). Industri Kreatif Berbasis Lokalitas, Dialektika Sastra Tengger, Using, Dan Representasi Identitas. Makalah Kongres Bahasa Indonesia X. Bidang Pengembangan Pembinaan Bahasa Kementerian Pendidikan dan kebudayaan, Jakarta 2013.

Ainin, Nurul \& Dwikoranto. (2019). Implementasi Model Pembelajaran Problem Based Instruction Untuk Meningkatkan Kemampuan Berpikir Kreatif Siswa Materi Alat Optik. Jurnal Inovasi Pendidikan Fisika. Vol. o8 No. 03. ISSN: 2302-4496.

Daniah. (2016). Kearifan Lokal (Local Wisdom) Sebagai Basis Pendidikan Karakter. Jurnal Pendidikan PIONER. Vol 5 No 2. 2016. Fakultas Tarbiyah dan Keguruan UIN Ar-Raniry. Darussalam Banda Aceh

Djumingin, S., (2016). Perencanaan pembelajaran bahasa, satra dan daerah: Teori dan penerapannya. UNM Makasar.

Harsono, A. (2005). Jurnalisme Sastrawi. Jakarta: Yayasan Pantau Kurnia, SS. (2002). Jurnalisme Sastra. Jakarta: Gramedia Pustaka Utama Giddens, Anthony. (2001). Bagaimana Globalisasi Merombak Kehidupan Kita. Jakarta: Gramedia.

Nurhayati. Pemertahanan Dulmuluk Dalam kaitannya Dengan Pengembangan Industri Kreatif Berbasis Budaya Lokal. Makalah Kongres Bahasa Indonesia X. Bidang Pengembangan Pembinaan Bahasa Kementerian Pendidikan dan kebudayaan, Jakarta 2013.

Ningsi, Sri. (2013). Rumah Dongeng Sebagai Industri Pendidikan karakter Bangsa. Makalah Kongres Bahasa Indonesia X. Bidang Pengembangan Pembinaan Bahasa Kementerian Pendidikan dan kebudayaan, Jakarta 2013.

Nurhayati. (2013). Pemertahanan Dulmuluk Dalam kaitannya Dengan Pengembangan Industri Kreatif Berbasis Budaya Lokal. Makalah Kongres Bahasa Indonesia X. Bidang Pengembangan Pembinaan Bahasa Kementerian Pendidikan dan kebudayaan, Jakarta 2013. 
Maria Elka, Pangestu, (2008b). Buku 2 : Rencana Pengembangan 1 Subsektor Industri Kreatif. Kelompok Kerja Indonesia Design Power: Departemen Perdagangan RI. Jakarta.

Rohana Sufia, Sumarmi, Ach. Amirudin. (2016). Kearifan Lokal Dalam Melestarikan Lingkungan Hidup (Studi Kasus Masyarakat Adat Desa Kemiren Kecamatan Glagah Kabupaten Banyuwangi). Jurnal Pendidikan: Teori, Penelitian, dan Pengembangan Volume: 1 Nomor: 4 Bulan April Tahun 2016. Pendidikan Geografi Pascasarjana-Universitas Negeri Malang.

Sukmadinata, Nana Syaodih. (2009). Metode Penelitian Pendidikan. Bandung: PT Remaja Rosdakarya.

Suyitno, Imam. (2012). Pengembangan Pendidikan Karakter Dan Budaya BangsaBerwawasan Kearifan Lokal. Jurnal Pendidikan Karakter, Tahun II No1. Februari 2012.

Howkins, Jhon. (2001). The Creative Economy: How People Make Money from Ideas. United Kingdom: Penguin.

Pramuniati, Isda. (2009). Implementasi Soft Skill Melalui Learning Revolution Sebagai Upaya Peningkatan Kualitas Lulusan Perguruan Tinggi. Penyunting, Sofendi, Seminar dan Rapat BKS Tahunan ke-5 BKS-PTN Wilayah Barat Bidang Bahasa. PROSIDING. Lembaga Bahasa dan FKIP. Universitas Sriwijaya.

Rohana Sufia, Sumarmi, Ach. Amirudin. (2016). Kearifan Lokal Dalam Melestarikan Lingkungan Hidup (Studi Kasus Masyarakat Adat Desa Kemiren Kecamatan Glagah Kabupaten Banyuwangi). Jurnal Pendidikan: Teori, Penelitian, dan Pengembangan Volume: 1 Nomor: 4 Bulan April Tahun 2016.

Rinitami Njatrijani. (2018). Kearifan Lokal Dalam Perspektif Budaya Kota Semarang. Edisi Jurnal (ISSN: 0852-011) Volume 5, Edisi 1, September 201816 Gema Keadilan Edisi Jurnal.

Sumargono, dkk, (1992). Profil Provinsi Jambi. Yayasan Bhakti Wawasan Nusantara. Jakarta.

Syafi'ie, Imam. (1998). Retorika Menulis. Departemen Pendidikan dan kebudayaan Direktorat Jenderal Pendidikan Tinggi Proyek Pengembangan Lembaga Pendidikan Tenaga Kependidikan. Jakarta.

Sukmadinata, Nana Syaodih. (2009). Metode Penelitian Pendidikan. Bandung: PT Remaja Rosdakarya.

Sumadiria, AB Haris. (2010). Jurnalistik Indonesia, Menulis berita dan Feature.Gramedia. Jakarta

Suyitno, Imam. (2012). Pengembangan Pendidikan Karakter Dan Budaya BangsaBerwawasan Kearifan Lokal. Jurnal Pendidikan Karakter, Tahun II No1. Februari 2012. 
Sukamto, Katharina Endrina. (2013). Keanekaragaman Bahasa dan Industri Kreatif Di Indonesia: Adakah Peluang Bagi Penguatan Bahasa Indonesia di Dunia Internasional. Maklah Kongres Bahasa Indonesia X. Badan Pengembangan Dan Pembinaan Bahasa. Kementerian Pendidikan dan Kebudayaan. Jakarta.

Siswanto, Wahyudi. (2014). Cara Menulis Cerita.Adiyta Media Publishing. MALANG.

Taum, Yoseph Yapi. (2013). Sastra Lisan Dan Ekonomi Kreatif: Kasus Legenda Pen dan Nogo Masyarakat Lamaholot. Makalah Kongres Bahasa Indonesia X. Bidang Pengembangan Pembinaan Bahasa Kementerian Pendidikan dan Kebudayaan, Jakarta. 